\title{
THE EFFECTS OF HOMOGENEOUS AND HETEROGENEOUS PUSHED OUTPUT INSTRUCTIONS ON SPEAKING COMPLEXITY
}

\author{
Parviz Ghasedi \\ English Department, Faculty of Humanity, University of Zabol, Iran \\ E-mail: ghasedi.p.988@ gmail.com \\ Habibollah Mashhady \\ English Department, Faculty of Humanity, University of Zabol, Iran \\ E-mail: mashhadyh@uoz.ac.ir \\ Farideh Okati \\ English Department, Faculty of Humanity, University of Zabol, Iran \\ E-mail: farideh.okati@uoz.ac.ir
}

\begin{abstract}
APA Citation: Ghasedi, P., Mashhady, H., \& Okati, F. (2017). The effects of homogeneous and heterogeneous pushed output instructions on speaking complexity. English Review: Journal of English Education, 6(1), 11-20. DOI: 10.25134/erjee.v6i1.766.
\end{abstract}

Received: 28-08-2017

Accepted: 31-10-2017

Published: 01-12-2017

\begin{abstract}
This study was set out to investigate the efficacy of homogeneous and heterogeneous pushed output based instruction on upper-intermediate EFL learner' speaking complexity. To do so, 41 (17 males and 24 females) EFL learners were selected from University of Zabol based on the results of OPT. Then, they were put in control and experimental groups based on the predetermined criteria. Retelling and decision making tasks were used in the treatments of experimental groups while control group received placebo during 15 sessions, twice a week. Public versions of IELTS speaking test were used as pre/post-test. The results of Independent sample t-test indicated that experimental groups outperformed control group. On the other hand, statistical analyses showed no significant differences between male and female speech complexity. To sum up, the findings demonstrated the fruitful effects of collaborative pushed output activities on speaking sub-skills. Likewise, the results suggested the implementation of similar strategies in the development of male and female speaking dimensions. Based on the findings, it can be claimed that teacher preparation programs should put teaching speaking on their list of priorities and provide courses on effective strategies for the development of speaking dimensions through implementing the main tenants of pushed output hypothesis.
\end{abstract}

Keywords: homogeneous, heterogeneous, complexity, speaking, pushed output

\section{INTRODUCTION}

Considering specific role for output to practice what language learners internalized as comprehensible inputs in educational contexts, Swain (1985) introduced the notion of pushed output hypothesis and notes that it helps learners process comprehensible input more effectively (Basterrechea, Mayo \& Leeser, 2014). Pushed output reflects the process of practicing written or oral outcomes accurately and effectively (Swain, 2005).

Daring to criticize Krashen's (1985, p.61) strong claims that "comprehensible input is the only true cause of second language acquisition", Swain $(1985,1998,2000)$ contemplates specific functions for output hypothesis that makes learners aware of their incapability in using the intakes in their outputs during conveying their intentions (Byrne, 2012; Thwaites, 2014). Swain (1985, $1998,2000)$ summarizes the main functions of pushed output under three titles of noticing/consciousness-raising, hypothesis testing, and metalinguistic. Nation (1990) asserts that such main functions of pushed 
output will inspire EFL/ESL learners to implement what they learned in interactions with their peers or teachers. The repetitions of such activities lead to the automatic use of lexical and grammatical structures which consequently improve their language proficiencies.

Generally speaking, pushed output hypothesis was proposed with the promise of boosting learners' productive (oral or written) competence. On the other hand, developing learners' oral subs-kills, complexity, accuracy, and fluency, is viewed as the ultimate goal of learning English in EFL/ESL contexts (McCarthy, 1998). Moreover, Alonso (2014) considers speaking as the building block for learning listening, reading, and writing. Likewise, Celik and Yavuz (2015) add that speaking is the corner stone of conducting communicative role of language. On the other side, a conclusive review of the related studies indicates that one of the big challenges of EFL learners is producing accurate, coherent, lexically dense, and fluent utterances (Alonso, 2014; Dahmardeh, 2009). Furthermore, teaching speaking sub-skills, especially in EFL countries, confronted with lots of problems because a native like oral outputs needs a combination of "phonetic, phonological prosodic, lexical, syntactic, semantics and pragmatic" (Osada, 2004, p. 56) knowledge.

With the emergence of pushed output hypothesis and its emphasis on providing learners with the opportunities to use target language in negotiation based activities, this problem seems to be resolved. Some studies investigated the efficacy of pushed output in developing learner syntactic and grammatical accuracy or reading comprehension (DoneschJezo, 2011; Ertürk, 2013; Tabatabaei \& Yakhabi, 2009). Moreover, Sadeghi-Beniss and Edalati-Bazzaz (2014) investigated the effects of pushed output on speaking fluency and accuracy. However, no study investigated the effects of pushed output on speaking complexity. Likewise, there is no valid long term research project on the efficacy of pushed output in developing speaking sub-skills. Accordingly, this study was set out to fill the mentioned gaps and find new strategies for developing learner speaking complexity through implementing main tenants of pushed output hypothesis.

\section{The role of input in language acquisition}

The proposed theories of first language acquisition (such as behaviorists, nativists, and functional) and that of L2 acquisition, (such as input hypothesis and output hypothesis) attach different significance (principal or secondary) to the role of input in language development (Ellis, 2008). From the behavioristic perspective, language input, which consists of the "production of correct response to stimuli" (Brown, 2007, p. 26), plays a vital role in language acquisition (Ellis, 2008). For nativists, it is a premium trigger for inspiring the pre-existed abilities (Ellis, 2008). Similarly, constructivists highlight the significance of input and interaction in learning the target language (Ellis, 2008).

Krashen (1981) regards it as the main criterion for learning and advancement and notes that input provides incidental and sufficient data for development. Krashen (1985) believes that if language learners are provided with lots of understandable data in different formats (oral, written, or pictorial), they will acquire $\mathrm{L} 2 \mathrm{He}$ introduces the notion of " $i+1$ " and argues that, a vital issue regarding comprehensible input is the fact that learners should be exposed to the "input language that contains structures a bite beyond his or her current levels of competence" (Krashen, 1981, p. 100).

According to Krashen (1982), the fundamental inspiration to comprehend the structures that we have not ace yet $(\mathrm{i}+1)$ is our abilities to use our already mastered knowledge, lexico-grammatical knowledge, logical information, and our insight into the world. Put another way, he asserts that in SLA, we use more than our lexical and grammatical competence. Furthermore, Krashen (1982) accentuates that learner should focus on the meaning of the messages that directed at him/her, not their structural forms. Likewise, Krashen (1982) believes that we should not push learner to speak. He adds that although learners with different proficiency levels start talking at different points in time, we should not expect them to produce accurate, well-formed, and precise outputs at 
the beginning. Therefore, we ought to give them the chance to talk when they feel ready for it and tolerate their grammatical and lexical errors.

\section{The role of pushed output in language acquisition}

Swain (1995) considers a significant place for input in educational contexts. However, she notes that comprehensible input cannot lead to the advancement. Language learner should gain enough opportunities to process the received inputs and implement them in their outputs (Van Patten, 2002). Output is defined as linguistic outcomes that learners produce (orally or in written) to convey their intentions, wants, desires, or ideas (Kumaravadivelu, 2006; Van Patten, 2003).

Nation (2011) notes that pushed connotes the cooperation process between interlocutors and pushed output implies pushing learners to use their background knowledge to produce outputs that are lexically dense and grammatically correct. Pushing students to practice and revise their outputs seems emergence for becoming competent communicators (Byrne, 2012). Accordingly, Swain (1985) numbers main functions of pushed output as noticing, hypothesis testing, and metalinguistic.

Gass (2003) views noticing as a factor that connects language comprehension to language generation. Donesch-Jezo (2011) indicates that noticing triggers the cognitive creation of new grammatical and lexical knowledge or integration of knowledge that stored in memory. Likewise, noticing function of POH triggers essential intellectual procedures such as psychological comparison (Muranoi, 2007). Research represents two main benefits of noticing as 'noticing the holes' and 'noticing the gap' (Muranoi, 2007; Swain, 1998). The first one informs students of their weakness points in converting their thoughts into target language words and structures (Byrne, 2012; Schmidt \& Frota, 1986). The second one makes them aware of the distances between their oral or written outputs and those of more proficient cocommunicators (peers or teachers) or native speakers (Izumi, 2003; Muranoi, 2007; Swain,
1998).

The second function of pushed output relates to the facts that during interaction with peers or with proficient speakers or writers, learners test different outputs and receive positive or negative feedbacks, which consequently lead to the internalization of the more (pragmatically and syntactically) appropriate ones (Kumaravadivelu, 2006). In the same line, it is argued that hypothesis testing set the grounds for learners' use of production skills to test whether the newly shaped hypothesis about the form and manner of conveying their intentions are meaningful and well-formed or not (Qin, 2008; Swain, 1995). Concerning the third function of output, metalinguistic function, Swain (1998, p. 68) notes that "learners use language to reflect on language use". Kumaravadivelu (2006) asserts that metalinguistic function of $\mathrm{POH}$ refers to the fact that learners consciously reflect on the language system. He mentions that learners may consciously think about the phonological, lexical, and grammatical roles of the TL in order to be more fluent and accurate in their productions.

\section{Speaking complexity}

The review of the related literature indicates that speaking has three main dimensions of complexity, accuracy, and fluency (Skehan, 1998; Skehan \& Foster, 1999). Since some studies were done on speaking fluency and accuracy, this study focused on the efficacy of pushed output in developing speaking complexity. Complexity concerns on the lexical density, grammatical well-formednes, and the richness of utterances produced by interlocutors (Housen, Kuiken, \&Vedder, 2012). Skehan and Foster (1999) assert that complexity refers to the students' abilities to talk soundly and cohesively. Saslow et al., (2014, p. 258) summarize the key features of linguistically complex speech as using more "exclusive words (such as but, except, however, and unless), tentative words (such as maybe, perhaps, hesitant, and guess), negations (such as never, neither, without, and cannot), and discrepancies (such as should, would, and wish)". In the language learning and teaching 
contexts, the mastery of oral ability becomes such a priority for many foreign or second language learners that many language learners evaluate the effectiveness of the course as well as their proficiencies on the basis of their improvement in speaking sub-skills (Brown \&Yule, 1983; Richards, 2008). Moreover, Rivers (1981) climes that the capacity to talk second or foreign language empowers learners to see new connections and opportunities and puts forth that speaking enables individuals to responds to different people and circumstances.

Skehan (2009) considers an antagonistic relationship among fluency, accuracy, and complexity. He states that learner cannot focus on the three dimensions simultaneously (because of the law capability of working memory). Others believe that learners may focus on one dimension in specific points in time (Gilabert, 2007; Robinson, 2001; Skehan \& Foster, 1999). In the eyes of Ellis (1994), the main cause of such challenges is the fact that the psycholinguistic processes required in TL production (speaking or writing) are different from its comprehension (reading or listening). Furthermore, he mentions that in the process of acquiring grammatical and lexical knowledge, learners must focus on input and monitor his/her outcomes, results in interference between fluent and accurate speech.

Yuan and Ellis (2003) claim that pretask planning had significant effects on learners' speaking complexity; however its effects on speech accuracy were not fruitful. Likewise, the results of Birjandi and Alipour (2010) revealed that the effects of noncollaborative pre-task planning on learners' speaking accuracy were more effective and fruitful than collaborative pre-task planning. On the other hand, the collaborative pre-task planning group outperformed the noncollaborative pre-task planning group concerning speech complexity. In a comparative study, Tabatabaei and Yakhabi (2009) compared the effects of input and output on EFL learners' speaking accuracy and complexity. They collected data from 60 female EFL learners. Their findings indicated that input was effective in developing speaking complexity. However, output was more effective in developing learner speech accuracy. Moreover, the results of Basterrechea et al., (2014) showed that the use of output based instruction in language classrooms provided learners with the appropriate and accurate speech which could be used as a model for novice learners to modify their outcomes and paid specific attentions to structures of native like speech.

In sum, some studies approved the significant effects of pushed output in language classrooms. However, there is no valid quantitative research project on the efficacy of pushed output in developing learner speaking fluency, accuracy, and complexity (Thwaites, 2014). On the other hand, one of the big challenges of EFL teacher, especially in Iran, is developing learners' ability to produce lexical dense, coherent, appropriate, and to the points utterances (Mohammadi, Gorjian, \& Pazhakh, 2014). Therefore, this study was set out with the intention of implementing the main tenants of pushed output hypothesis in order to find new strategies for developing speaking complexity. Accordingly, the following research questions were proposed.

1. Does homogeneous pushed output have any significant effect on EFL learners' speaking complexity?

2. Does heterogeneous pushed output have any significant effect on EFL learners' speaking complexity?

3. Does gender have any significant effect on EFL learners' speaking complexity?

\section{METHOD}

This study was done at the second semester of 2016 academic year. The upper-intermediate EFL learners (17males and 24 females) were selected based on the results of OPT. The age of the participants ranged from 20 to 29. They were selected based on the results of Oxford Placement Test (OPT). Accordingly, those whose score were between 40-47 were selected as the sample of this study. Then, the selected samples were put in three groups of Control Group (CG), Homogeneous Group (HG), and heterogeneous or Asymmetrical Group (AG). Table 1 represents group 
specification.

Table 1. Groups specification

\begin{tabular}{lcccccc}
\hline & & \multicolumn{2}{c}{ Gender } & \multicolumn{3}{c}{ Education } \\
\cline { 3 - 7 } Groups & Total No & Male & Female & BA & MA & Ph.D. \\
\hline CG & 14 & 7 & 7 & 8 & 5 & 1 \\
HG & 13 & 5 & 8 & 11 & 2 & 0 \\
AG & 14 & 5 & 9 & 10 & 4 & 2 \\
Total & 41 & 17 & 24 & 29 & 11 & 3 \\
\hline
\end{tabular}

As Table 1 shows 29 members of the sample were BA, 11 were MA, and 3 were $\mathrm{Ph}$.D. students. They were put in CG randomly but the member of $\mathrm{HG}$ were those students whose scores were not more than one standard deviation bellow or above the predetermined cut scores and the members of AG were those whose scores were more than one standard deviation bellow or above the predetermined cut score.

At the beginning of the study, the researcher explained the aims and significance of the study to the participants and assured them that the information would be used just for research purposes and would be kept quite confidential. Moreover, they were informed that the results of their responses would not affect their English marks.

IELTS speaking test was used to measure learners' speaking complexity at the beginning of the study. The participants participated in face to face interview with the researcher in an empty room in the Univercity of Zabol, Faculty of Humanity. After that, they studied 7 lessons of New Interchange 2 during 8 weeks, twice a week for about 45 minutes each session. CG participated in normal speaking classroom. The subjects listened to different audio files of the book. Then, they were given 5 minutes to think about them. After that, the files were plaid again and teacher asked some general and specific questions about the plaid files. The interactions between subjects were limited in $\mathrm{CG}$ and much of the time of the class was spent on teacher explanations and managements. On the other hand, the HG and AG participated in task based classroom. The notion and aims of pushed output were explained to them at the begging of the study and they were informed of how they should cooperate and push their partners to use more complex structures in their outputs. Two main tasks, retelling and decision making task, were used in such classroom. The subjects were supposed to push each other toward using more lexically dense utterances during task completion. Moreover, they inspired each other to speak more accurately and coherently. At the end of the study another version of IELTS speaking test was used as posttest. The interviews were audio recorded by Philips GoGear Mix MP3 Player. The recorded files were transcribed and coded for statistical analyses.

After transcribing the collected data, they were coded for further analyses. To quantify speech complexity the authors used lexical density. Accordingly, the number of uttered lexical words was divided by deliver words (based on Norris \& Ortega, 2009; Rahimpour, 1999). Moreover, in line with Rahimpour (2008) and Rahimpour and Mehrang (2010), the obtained results were multiplied by 100 (to make them more tangible). After coding the collected data and entering them into SPSS, descriptive statistics and Independent samples t-test were run to answer the research questions.

\section{RESULTS AND DISCUSSION}

The first research question investigated the efficacy of homogeneous pushed output based instructions on EFL learner speaking complexity. Independent sample t-test was used to answer this question. Table 2 shows the results of descriptive statistics and Table 3 presents the results of Independent sample ttest. 
Parviz Ghasedi, Habibollah Mashhady, \& Farideh Okati

The effects of homogeneous and heterogeneous pushed output instructions on speaking complexity

Table 2. Descriptive statistics of pre/post-test for $C G, H G$, and $A G$

\begin{tabular}{|c|c|c|c|c|c|c|}
\hline & & Groups & $\mathrm{N}$ & $\mathrm{M}$ & SD & SE \\
\hline \multirow[t]{3}{*}{ Complexity } & Pre-test & CG & 14 & 29.330 & 2.292 & .612 \\
\hline & & HG & 13 & 29.364 & .764 & .211 \\
\hline & & AG & 14 & 29.384 & 1.997 & .533 \\
\hline \multirow[t]{3}{*}{ Complexity } & Post-test & CG & 14 & 35.366 & 4.097 & 1.095 \\
\hline & & HG & 13 & 39.496 & 1.650 & .457 \\
\hline & & $\mathrm{AG}$ & 14 & 45.562 & 2.079 & .555 \\
\hline
\end{tabular}

Table 2 indicates that the mean scores of $\mathrm{CG}(\mathrm{M}=35.366), \mathrm{HG}(\mathrm{M}=39.496)$, and $\mathrm{AG}$ of the study. Therefore, Independent sample ttest was used as further analysis.

$(\mathrm{M}=39.496)$ are rather different at the posttest

Table 3. Results of Independent Samples t-test for the efficiency of HG

\begin{tabular}{lcccccl}
\hline & $\mathrm{F}$ & $\mathrm{t}$ & $\mathrm{df}$ & $\begin{array}{c}\text { Sig. } \\
(2 \text {-tailed) }\end{array}$ & M Difference & $\begin{array}{l}\text { Std. Error } \\
\text { Difference }\end{array}$ \\
\hline Complexity & 6.106 & -2.080 & 24 & $.001^{*}$ & -4.13 & 1.065 \\
\hline Note. ${ }^{*}=\mathrm{p}<.05$. & & & & & &
\end{tabular}

The result of Independent sample t-test indicated significant differences between the mean scores of $\mathrm{CG}$ and $\mathrm{HG}(\mathrm{F}=6.106, \mathrm{t}=$ $2.080, \mathrm{df}=24, \mathrm{p}=.001)$. Therefore, it can be claimed that homogeneous pushed output based instructions have significant effects on EFL learner speaking complexity.

Next, the second research question analyzed the effects of heterogeneous pushed output based instructions on speaking complexity. Descriptive statistics of the participants in pre/post-test of the study are presented in Table 1. Accordingly, the mean score of $A G(M=45.562)$ was slightly higher than $\mathrm{CG}(\mathrm{M}=35.366)$. Independent sample ttest was used to see whether these differences reached statistically significant level or not.

Table 4. Results of Independent Samples t-test for the efficiency of AG

\begin{tabular}{lcccccc}
\hline & $\mathrm{F}$ & $\mathrm{t}$ & $\mathrm{df}$ & $\begin{array}{c}\text { Sig. } \\
(2 \text {-tailed })\end{array}$ & M Difference & $\begin{array}{l}\text { Std. Error } \\
\text { Difference }\end{array}$ \\
\hline Complexity & 5.011 & -3.458 & 24 & $.000^{*}$ & -10.196 & .289 \\
\hline Note. ${ }^{*}=\mathrm{p}<.05$. & & & & & &
\end{tabular}

Table 4 indicates that there are significant differences between the effects of $\mathrm{CG}$ and $\mathrm{AG}$ on EFL learners speaking complexity. In sum, the results show the efficacy of heterogeneous pushed output based instruction on upper-intermediate EFL learners speaking complexity.

Further, the third research question checks the potential differences between male and female learners' speech complexity.

Table 5. Descriptive statistics of pre/post-test concerning learner gender

\begin{tabular}{|c|c|c|c|c|c|c|}
\hline & & Groups & $\mathrm{N}$ & $\mathrm{M}$ & SD & SE \\
\hline \multirow[t]{2}{*}{ Complexity } & Pre-test & Male & 17 & 29.309 & 1.492 & .472 \\
\hline & & Female & 24 & 29.413 & 1.555 & .377 \\
\hline \multirow[t]{2}{*}{ Complexity } & Post-test & Male & 17 & 42.486 & 3.411 & 1.078 \\
\hline & & Female & 24 & 42.733 & 3.806 & .923 \\
\hline
\end{tabular}

Descriptive statistics indicated that the mean scores of male and female learners' speaking complexity $\left(\mathrm{M}_{\text {Male }}=29.309\right.$;

$\mathrm{M}_{\text {Female }}=29.413$ ) were rather similar at the pretest of the study. Likewise, their mean scores were rather similar at the post-test of the study
$\left(\mathrm{M}_{\mathrm{Male}}=42.486 ; \mathrm{M}_{\mathrm{Female}}=42.733\right)$. A series of Independent Samples t-test was run to check the potential differences in participants speaking complexities' scores with respect to their gender. The results are shown in Table 6. 
Table 6. Independent Samples t-test to compare male and female complexity scores on post-test

\begin{tabular}{lcccccc}
\hline & $\mathrm{F}$ & $\mathrm{t}$ & $\mathrm{df}$ & $\mathrm{Sig}(2$-tailed) & $\begin{array}{c}\mathrm{M} \\
\text { Difference }\end{array}$ & $\begin{array}{c}\text { Std. Error } \\
\text { Difference }\end{array}$ \\
\hline Complexity & .031 & -.169 & 25 & $.867^{\mathrm{a}}$ & -.247 & 1.462 \\
\hline Note $^{\mathrm{a}}=\mathrm{p}>.05$. & & & & & &
\end{tabular}

Table 6 indicates no significant difference between male and female learners' speaking complexity $(\mathrm{F}=.031, \mathrm{t}=-.169, \mathrm{df}=25$, $\mathrm{p}=.867)$. Accordingly, it can be concluded that gender is not a deterring factor in developing learner speaking complexity.

From the analysis, it can be stated that $\mathrm{HG}\left(\mathrm{M}_{\text {complexity }}=39.496\right)$ and $\mathrm{AG}\left(\mathrm{M}_{\text {complexity }}=\right.$ 45.562) outperformed $\mathrm{CG}\left(\mathrm{M}_{\text {complexity }}=\right.$ 35.366). The significance of the differences among mean scores are tested through Independent samples t-test. The results revealed that such differences were statistically significant. To sum up, those learners who benefit from pushed output activities (in homogeneous or heterogeneous groups) use more lexical morphemes such as nouns, verbs, and adverbs in their outputs.

The results are consistent with the findings of Byrne (2012) that implementing pushed output exercises draw learner attentions to the linguistics structures (grammatical and discourse competence) of their utterances. Similarly, Ertürk (2013) mentions that engaging learners in such activities leads to the appropriate usage of conditional sentences in their interactions. On the other hand, the results conflict with those found by Sadeghi- Beniss and Edalati-Bazzaz (2014). They clime that pushed output activities is not effective in developing learner speaking sub-components, especially speaking fluency. They relate their results to the nature of pushed output activities.

The beneficial effects of pushed output in this study support Swain's (1985) clime and her notion of pushing. The results of this study can be justified through considering the fruitful effects of the main functions of pushed output (noticing, hypothesis testing, and metalinguistics). As Swain (1985) argues such functions help language acquisition in different ways. Besides, the fulfillment of pushed output tasks need interaction (especially student-student interaction). The nature of interactions and feedbacks (negative or positive) in intraclass groups in this study inspires participants to produce more lexically dense and linguistically complex utterances. Moreover, such activities give learner the opportunities to take more responsibility for the accuracy, coherence, and complexity of their speech, consequently, lead to advancement. Likewise, learners' feedback in this study gives the group members second or third chance to repeat their utterances which make their productions more complex.

On the other hand, the results of this study do not detect significant differences between male and female EFL learners' speaking complexity. The findings are not in the same line with the results of Khomeijani et al., (2009). They mention that male speech is more accurate and complex while females are more fluent. On the other hand, the results are supported by the findings of more recent studies (Gholizade, 2013; Majidifard et al., 2014). Gholizade (2013) mentions that there is no significant difference between learners oral outputs concerning their gender. Moreover, Majidifard et al. (2014) assert that male and female learners' speaking fluency and complexity are not significantly different. It seems that male and female differences in using language are mostly related to the degree of politeness (Haas, 1979), assertiveness (Lakoff, 1975), and the implementation of discourse markers (Alami, Sabbah, \&Iranmanesh, 2012).

\section{CONCLUSION}

While many studies are needed to be conducted to investigate the efficacy of pushed output in developing speaking complexity, especially in EFL contexts, the results emerged from the statistical analyses of the current study made it certain that pushed output had valuable effects on speaking subcomponents. Likewise, findings indicated that grouping learners homogeneously or 
heterogeneously increase fruitful interaction among learners which could not be observed in teacher centered classroom. On the other hand, the results indicated that gender is not a determining factor in developing upperintermediate EFL learners speaking complexity.

Taking the significant role of speaking in EFL/ESL academic contexts into account and paying specific attention to the factors, such as having no opportunity to use English in real context, teacher centered classroom, and lack of language teacher attention to the speaking sub-components (Mohammadi, Gorjian, \& Pazhakh, 2014) that are considered as the main challenges of EFL learners, one should welcome any fruitful strategy that boost learner output complexity. Therefore, the beneficial effects of pushed output based instruction, as presented in this study, can be regarded as an allegory to pay more attention to student centered classrooms in which learners are pushed to use target language more accurately in appropriate context in order to convey their ideas or desires.

The findings of this research help to add new insights to the literature of pushed output hypothesis and provide fruitful new teaching guidelines. Moreover, the results can be of great help for material developers and text book writers. Besides, such findings suggest that teacher preparation programs should make the development of speaking sub-skills an integral part of program to equip teachers with a wide array of effective oral development strategies.

The first limitation that the researcher confronted with in this study was the limited number of participants. Likewise, just the upper-intermediate level was studied. Finally, this study used lexical density as the indicator of speech complexity. Therefore, studding large sample, different levels, or using different indicators of complexity (AS-units) may lead to more fruitful results.

\section{REFERENCES}

Alami, M., Sabbah, M., \& Iranmanesh, M. (2012). Gender and discourse difference: An investigation of discourse markers in Persian male-female casual conversation. Archives Des Sciences, 65(7), 203-223.
Alonso, A. R. (2014). Teaching speaking: An exploratory study in two academic contexts. Porta Linguarum, 22, 145-160.

Basterrechea, M., Mayo, M. P. G., \& Leeser, M. J. (2014). Pushed output and noticing in a dictogloss; task implementation in the CLIL classroom: A case study on teachers' insights into their students' mother tongue, Porta Linguarum 22(22), 7-22.

Birjandi, P., \& Alipour, S. (2010). Comparing the effect of individual and group pre-task planning on EFL learners' accuracy and complexity in speaking. JELS, 1(4), 1-22.

Brown, C., \& Yule, C. (1983). Teaching the spoken language. Cambridge: Cambridge University Press.

Brown, H. D. (2007). Principles of language learning and teaching (5th ed.). New York: Pearson Longman.

Byrne, S. M. (2012). A study into the effectiveness of pushed/nonpushed spoken output tasks focusing on upper intermediate students in the EFL classroom. Unpublished MA Dissertation. University of Central Lancashire, 1-73.

Celik, O., \& Yavuz, F. (2015). The relationship between speaking grades and listening grades of university level preparatory students. Procedia - Social and Behavioral Sciences, 197, 2137 - 2140.

Dahmardeh, M. (2009). Communicative textbooks: English language textbooks Iranian secondary school. Linguistik Online, 40(4), 45-61.

Donesch-Jezo, E. (2011). The role of output and feedback in second language acquisition: A classroom-based study of grammar acquisition by adult English language learners. ESUKA JEFUL, 2(2), $9-28$.

Ellis, R. (1994). The study of second language acquisition. Oxford: Oxford University Press.

Ellis, R. (2008). The study of second language acquisition. Oxford: Oxford University Press.

Ertürk, N. O. (2013). Effects of visually enhanced input, input processing and pushed output on grammar teaching. Portal Linguarum, 20, 153-167.

Gass, S. M. (2003). Input and interaction. In C. Doughty \& M. Long (Eds.), Handbook of second language acquisition (pp. 224-255). Oxford: Blackwell.

Gholizade, R. (2013). The investigation of differential effects of recast and metalinguistic feedback on accuracy, fluency, and complexity of speaking performance of male and female EFL learners. Journal of Novel Applied Sciences, 2(9), 417-428.

Gilabert, R. (2007). Effects of manipulating task complexity on self-repairs during L2 oral production. International Review of Applied Linguistics, 45, 215-240.

Haas, A. (1979). The acquisition of genderlect. In J. Orasnu, M. Slater \& L. Adler (Eds.), Language, sex, and gender: Does la différence make a difference? (pp. 101-113). New York: Academy of Sciences. 
Izumi, S. (2003). Comprehension and production processes in second language learning: In search of the psycholinguistic rationale of the noticing hypothesis. Applied Linguistics 24 (2), 168-196.

Khomeijani, Farahani, A., \& Khaghani-Nejad, M. S. (2009). A study of task-based approach: The effects of task-based techniques, gender, and different levels of language proficiency on speaking development. Pazhuhesh-e Zabanha-ye Khareji, 49(4), 23-41.

Krashen, D.S. (1985). The input hypothesis: Issues and implications. England: Longman Group Limited.

Krashen, S. D. (1981). Second language acquisition and second language learning. Oxford: Pergamon.

Krashen, S. D. (1982). Principles and practice in second language acquisition. Oxford: Pergamon.

Kumaravadivelu, B. (2006). Understanding language teaching: From method to postmethod. New Jersey: Erlbaum.

Lakoff, R. (1975). Language and woman's place. Language in Society, 2(1), 45-80.

Majidifard, E., Shomoossi, N., \& Ghourchaei, B. (2014). Risk taking, gender and oral narrative proficiency in Persian learners of English. Procedia - Social and Behavioral Sciences, 98, 1085 - 1092.

McCarthy, M. (1998). Spoken language and applied linguistics. Cambridge: Cambridge University Press.

Mohammadi, M., Gorjian, B., \& Pazhakh, A. (2014). The effect of classroom structure on speaking skills of Iranian learners: A comparative study. International Journal of Language Learning and Applied Linguistics World (IJLLALW), 5(1), 472487.

Muranoi, H. (2007). Output practice in the L2 classroom. In Dekeyser, R. M. (Ed.), Practice in a second language: Perspectives from applied linguistics and cognitive psychology (pp. 51-84). Cambridge: Cambridge University Press.

Nation, I. S. P. (1990). Teaching and learning vocabulary. New York: Newbury House.

Nation, I. S. P. (2011). Second language speaking. In Hinkel, E. (Ed.), Handbook of research in second language teaching and learning (pp. 444-454). New York: Routledge.

Norris, J. M., \& Ortega, L. (2009). Towards an organic approach to investigating CAF in instructed SLA: The case of complexity. Applied Linguistics, 30, 555-578.

Osada, N. (2004). Listening comprehension research: A brief review of the past thirty years. Dialogue, 3 , 53-66.

Qin, J. (2008). The effect of processing instruction and dictogloss tasks on acquisition of the English passive voice. Language Teaching Research, 12(1), 61- 82.

Rahimpour, M. (1999).Task complexity and variation in interlanguage. In N., Jungheim, and P., Robinson (Eds.), Proceedings of the 3rd pacific language research forum (pp. 115-134). Japan: PacSLRF.
Rahimpour, M. (2008).Implementation of task-based approaches to language teaching. Research on Foreign Languages Journal of Faculty of Letters and Humanities, 41, 45- 61.

Rahimpour, M., \& Mehrang, F. (2010). Investigating effects of task structure on EFL learner's oral performance. English Language Teaching, 3(4), 10-17.

Richards, J.C. (2008). Growing up with TESOL. English Teaching Forum, 46(1), 2-11.

Rivers, W. (1981).Teaching foreign language skills. Chicago: University of Chicago Press.

Robinson, P. (2001). Task complexity, task difficulty, and task production: Exploring interactions in a componential framework. Applied Linguistics, 22(1), 27-57.

Sadeghi-Beniss. A. R., \&Edalati-Bazzaz, V. (2014) The impact of pushed output on accuracy and fluency of Iranian EFL learners' speaking. Iranian Journal of Language Teaching Research, 2(2), 5172.

Saslow, L. R., McCoy, S., Löwe, I. V. D., Cosley, B., Vartan, A., Oveis, C., Keltner, D., Moskowitz, J. T., \&Epel, E. S. (2014). Speaking under pressure: Low linguistic complexity is linked to high physiological and emotional stress reactivity. Psychophysiology, 51, 257-266.

Schmidt, R. W., \& Frota, S. (1986). Developing basic conversational ability in a second language: A case study of an adult learner of Portuguese. In R. R. Day (Ed.), Talking to learn: Conversation and second language acquisition (pp. 237-326). Cambridge, MA: Newbury House.

Skehan P., \& Foster, P. (1999).The influence of task structure and processing conditions on narrative retellings. Language Learning, 49(1), 93-120.

Skehan, P. (1998). A cognitive approach to language learning. Oxford: Oxford University Press.

Skehan, P. (2009). Modeling second language performance: Integrating complexity, accuracy, fluency and lexis, Applied Linguistics, 30(4), 510532.

Swain, M. (1985). Communicative competence: Some roles of comprehensible input and comprehensible output in its development. In S. Gass and C. Madden (Eds), Input in second language acquisition (pp. 235-256). New York: Newbury House.

Swain, M. (1995). Three functions of output in second language learning. In G. Cook and B. Seidlhofer (Eds.), Principle and practice in applied linguistics: Studies in honor of H.G. Widdowson (pp.125-44). Oxford: Oxford University Press.

Swain, M. (1998). Focus on form through conscious reflection. In C. Doughty and J. Williams, Focus on form in classroom second language acquisition. Cambridge: Cambridge University Press.

Swain, M. (2000). The output hypothesis and beyond: Mediating acquisition through collaborative dialogue. In J. P. Lantolf (Eds), sociocultural 
Parviz Ghasedi, Habibollah Mashhady, \& Farideh Okati

The effects of homogeneous and heterogeneous pushed output instructions on speaking complexity

theory and second language learning (pp. 97114). Oxford: Oxford University Press.

Swain, M. (2005). The output hypothesis: Theory and research. In E. Hinkel (Ed.), Handbook of research in second language teaching and learning (pp. 471-483). Mahwah, NJ: Lawrence Erlbaum.

Tabatabaei, O., \& Yakhabi, M. (2009).The effect of comprehensible input and comprehensible output on the accuracy and complexity of Iranian EFL learners' oral speech. The Journal of Applied Linguistics, 2(2), 218-248.
Thwaites, T. (2014). Research metrics: Calling science to account. Nature, 511(7510), 57-60. DOI: 10.1038/511S5.

Van Patten, B. (2002). Processing instruction: An update. Language Learning, 52, 755-803.

Van Patten, B. (2003). From input to output: A teacher's guide to second language acquisition. New York: McGraw-Hill.

Yuan, F., \& Ellis, R. (2003).The effects of pre-task and on-line planning on fluency, complexity and accuracy in L2 monologic oral production. Applied Linguistics, 24(1), 1-27. 